\title{
PENGARUH TERAPI BERMAIN CLAY TERHADAP KECEMASAN HOSPITALISASI PADA ANAK USIA 3-6 TAHUN
}

\author{
Heny Nurmayunita ${ }^{1}$, Apriyani Puji Hastuti ${ }^{2}$ \\ 1. Poltekes RS dr. Soepraoen Malang (Program Studi Keperawatan, henin.dhila@gmail.com) \\ 2. Poltekes RS dr. Soepraoen Malang (Program Studi Keperawatan, ns.apriyani@gmail.com)
}

\begin{abstract}
ABSTRAK
Pendahuluan Hospitalisasi pada anak merupakan suatu proses karena suatu alasan yang mengharuskan anak untuk tinggal di rumah sakit, menjalani terapi dan perawatan sampai anak dapat dipulangkan kembali kerumah. Selama proses tersebut, anak dapat mengalami berbagai kejadian berupa pengalaman yang sangat traumatik dan penuh dengan stres. Untuk mengatasi masalah kecemasan hospitalisasi anak usia pra sekolah 3-6 tahun dapat diberikan dengan terapi bermain Clay. Penelitian ini dibuat dengan tujuan mengetahui pengaruh pemberian terapi bermain Clay terhadap kecemasan hospitalisasi

Metode Penelitian ini menggunakan metode Pre Eksperimen dengan One group Pre-post test. Sampel dipilih dengan menggunakan teknik consecutive sampling dengan kriteria inklusi dan eksklusi dan didapatkan sampel sejumlah 20 orang. Variabel yang digunakan pada penelitian ini adalah terapi bermain Clay dan tingkat kecemasan hospitalisasi. Pengolahan data dan analisa data menggunakan uji $\mathrm{T}$ test.

Hasil Penelitian menunjukkan bahwa Ada Pengaruh Pemberian Terapi Bermain Clay Terhadap Kecemasan Hospitalisasi Anak Usia 3-6 Tahun Di Ruang Nusa Indah Rumah Sakit Tentara dr.Soepraoen Malang dengan menggunakan uji T Test dengan hasil $\propto 0,000$ yang kurang dari $<0,05$. Penelitian ini diharapkan dapat memberikan masukan pada bagian pelayanan kesehatan terutama rumah sakit yang memiliki ruang anak untuk menyediakan terapi bermain Clay dan terapi bermain lainnya sebagai salah satu media untuk menghilangkan kecemasan hospitalisasi pada anak khususnya Usia 3-6 tahun sesuai tahapan usianya.
\end{abstract}

Kata kunci: Clay, kecemasan hospitalisasi, anak

\begin{abstract}
Introdaction Hospitalization in children is a process for a reason that requires children to stay in the hospital, undergo therapy and care until the child can be returned home. During the process, children can experience various events in the form of experiences that are very traumatic and stressful. To overcome the problem of anxiety hospitalization for pre-school children 3-6 years old can be given with playing therapy Clay. This study was made with the aim of knowing the effect of giving Clay play therapy to the anxiety of hospitalization.
\end{abstract}

\section{Method}

This study used the Pre Experiment method with One group Pre-post test. Samples were selected using consecutive sampling technique with inclusion and exclusion criteria and a sample of 20 people was obtained. The variables used in this study were Clay's play therapy and the level of anxiety of hospitalization. Data processing and data analysis using the T test. Results Research shows that there is the effect of giving Clay Play Therapy to Hospitalization Anxiety for Children Aged 3-6 Years in Ruang Nusa Indah Army Hospital Dr. Soepraoen Malang by using the T Test with a result of $\propto 0,000$ which is less than $<0.05$. This research is expected to provide input to the health services section, especially hospitals that have children's space to provide Clay play therapy and other play therapies as one of the media to eliminate the anxiety of hospitalization for children especially ages 3-6 years according to the age stage.

Keywords: Clay, anxiety of hospitalization, child 


\section{PENDAHULUAN}

Hospitalisasi pada anak merupakan suatu proses karena suatu alasan yang direncanakan atau darurat mengharuskan anak untuk tinggal di rumah sakit, menjalani terapi dan perawatan sampai anak dapat dipulangkan kembali kerumah. Selama proses tersebut, anak dapat mengalami berbagai kejadian berupa pengalaman yang sangat traumatik dan penuh dengan stres (Supartini, 2012). Kecemasan sangat biasa dialami dan merupakan keadaan emosi yang normal. Namun pada beberapa orang termasuk anak mengalami kecemasan dan kekhawatiran yang berlebihan dapat menyebabkan mereka sulit untuk mengontrol pikiran dan perasaannya. Keadaan seperti itulah yang disebut sebagai gangguan kecemasan (Hildayani,dkk,2011). Pada anak usia pra sekolah, kecemasan yang paling besar dialami adalah ketika pertama kali mereka masuk sekolah dan kondisi sakit yang dialami anak.

Dari hasil studi pendahuluan di lakukan di ruang Nusa Indah Rumah Sakit dr Soepraoen Malang di dapatkan hampir 90\% pasien anak mengalami kecemasan karena hospitalisasi. Berdasarkan data tahun 2015 jumlah anak dirawat keseluruhan sebanyak 1125 anak. Data yang didapatkan peneliti terbaru didapatkan pada tahun 2016 dari bulan januari sampai bulan oktober sebanyak 1118. Jumlah anak usia 3-6 tahun yang dirawat pada bulan oktober sebanyak 38. Hasil wawancara didapatkan, ruangan masih menggunakan teknik orang ketiga, yakni melibatkan orangtua untuk mengatasi kecemasan hospitalisasi anak pada usia 3-6 tahun. Anak sering kali ketika mengalami kecemasan, akan menunjukkan perilaku menangis, histeris saat didatangi oleh petugas kesehatan, nafsu makan menurun, menolak tindakan, dan meminta untuk pulang kerumah.

Penyebab anak harus mengalami kecemasan hospitalisasi karena keadaan lingkungan yang baru atau lingkungan asing yang menjadikan anak tidak nyaman (Hawari, 2011). Dampaknya jika kecemasan anak tidak diatasi akan mengalami gangguan emosional, serta gangguan pertumbuhan dan perkembangan pada anak. Bermain memungkinkan anak mendapatkan pengalaman hidup yang nyata serta menemukan kekuatan dan kelemahannya sendiri karena bermain dapat dilakukan oleh anak yang sehat maupun sakit (Adriana, 2013).

Kecemasan anak prasekolah selama menjadi proses hospitalisasi dipengaruhi oleh berbagai faktor yaitu usia perkembangan, jenis kelamin, lama dirawat, pengalaman dirawat sebelumnya, system pendukung, dan mekanisme koping. Kecemasan pada anak prasekolah akan mengaktivasi hipotalamus dan selanjutnya melepaskan Hormone Corticotropic Realising Hormone (CRH). CRH menyebabkan hipofise anterior mengeluarkan Adenocorticotropic Hormone (ACTH). ACTH merangsang korteks adrenal melepaskan kortisol. Pemberian terapi 
bermain pada anak prasekolah yang dirawat dirumah sakit memberikan manfaat untuk kemampuan motorik halus anak, sekaligus merangsang kreativitas anak. Jika stressor kecemasan berupa perpisahan dapat diatasi maka tingkat kecemasan pada anak dapat menurun (Hockenbery, 2009).

Perasaan nyaman juga akan merangsang tubuh untuk mengeluarkan hormone endorphin. Peningkatan endorphin dapat menurunkan kecemasan pasien. Hormon endorphin merupakan hormone yang diproduksi oleh bagian hipotalamus di otak. Hormon ini menyebabkan otot menjadi rileks, sistem immune meningkat dan kadar oksigen dalam darah naik, sehingga dapat membuat pasien cenderung mengantuk dan dapat beristirahat dengan tenang. Hormon ini juga memperkuat sistem kekebalan tubuh untuk melawan infeksi dan dikenal sebagai morfin tubuh yang menimbulkan efek sensasi yang sehat dan nyaman. Selain mengeluarka hormone endorphin tubuh juga mengeluarkan GABA enkephalin. Zat-zat ini dapat menimbulkan efek analgesia sehingga nyeri pada anak prasekolah yang sakit dapat dikurangi atau dihilangkan. Jika stressor kecemasan yang dialami anak prasekolah dapat diatasi maka kecemasan yang dialami anak dapat menurun (Hockenbery, 2009). Penggunaan bahan clay merupakan bahan yang mudah didapatkan, mudah digunakan dan memiliki nilai ekonomis yang cukup terjangkau bagi seluruh kalangan masyarakat.

Untuk mengatasi masalah kecemasan hospitalisasi anak usia pra sekolah 3-6 tahun selain dengan melibatkan orangtua anak, dapat diberikan dengan terapi bermain. Salah satu macam terapi bermain yang sesuai dengan tahapan anak usia pra sekolah 3-6 tahun yaitu bermain Clay. Selama di rumah sakit permainan ini bisa dilakukan sendiri maupun dengan orang lain yaitu dampingan orangtua, perawat, maupun teman sebayanya yang ada di lingkungan sekitarnya.

\section{METODE}

Desain yang digunakan dalam penelitian ini adalah Pra eksperimen dengan pendekatan one group pre - post test design. Rancangan one group pra- post test design adalah mengungkapkan hubungan sebab akibat dengan cara melibatkan satu kelompok subjek Penelitian ini menggunakan data primer untuk mengetahui pengaruh pemberian terapi bermain Clay terhadap kecemasan hospitalisasi anak usia 3-6 tahun di Ruang Nusa Indah Rumah Sakit Tentara dr.Soepraoen Malang.

Populasi dalam penelitian ini adalah seluruh anak usia 3-6 tahun di Ruang Nusa Indah Rumah Sakit Tentara dr.Soepraoen Malang yang berjumlah 38 anak. Sampel dalam penelitian ini adalah sebagian anak usia 3-6 tahun di Ruang Nusa Indah Rumah Sakit Tentara 
dr.Soepraoen Malang dengan jumlah 20 anak. Teknik Sampling yang digunakan pada penelitian ini adalah Consecutive Sampling.

Dalam penelitian ini yang menjadi variabel independent adalah bermain Clay dan Variabel dependent dalam penelitian ini adalah Kecemasan Hospitalisasi. Instrumen yang merupakan alat ukur yang digunakan dalam penelitian ini berupa dua Skala Face Images Scale (FIS) dan Spence Children's Anxiety Scale For Preschool. Uji statistik yang digunakan adalah menggunakan T-test untuk menguji pengaruh pemberian terapi bermain Clay terhadap penurunan kecemasan pada anak usia prasekolah.

\section{HASIL}

\section{Karakteristik Responden}

Karakteristik responden berdasarkan Usia dan Jenis Kelamin Pada Anak Usia 3-6 Tahun Yang Mengalami Kecemasan Hospitalisasi. Berdasarkan tabel 5.1, didapatkan data bahwa dari 20 responden sebagian besar berusia 6 tahun sebanyak 12 responden $60 \%$ dan sebagian kecil responden berusia 3 tahun sebanyak 2 responden 10\%. Untuk jenis kelamin anak didapatkan dari 20 responden sebagian besar responden berjenis kelamin laki-laki sebanyak 13 responden $(65 \%)$ dan hampir setengahnya berjenis kelamin perempuan sebanyak 7 responden $(35 \%)$.

\section{Data Khusus}

Data khusus karakteristik berdasarkan tingkat kecemasan hospitalisasi anak usia 3-6 tahun di Ruang Nusa Indah Rumah Sakit Tentara dr.Soepraoen Malang sebelum dan sesudah perlakuan pemberian terapi bermain Clay.

1. Data Tingkat Kecemasan Hospitalisasi Anak Usia 3-6 Tahun Di Ruang Nusa Indah Rumah Sakit Tentara dr.Soepraoen Malang Sebelum dan Sesudah Di Berikan Terapi Bermain Clay.

Berdasarkan tabel 5.3, didapatkan data sebelum perlakuan bahwa dari 20 responden sebagian besar kecemasan ringan sebanyak 13 responden $65 \%$ dan hampir setengahnya kecemasan sedang sebanyak 7 responden 35\%. Dan sesudah perlakuan didapatkan sebagian besar tidak cemas $(60 \%)$ dan hampir setengahnya kecemasan ringan $(40 \%)$.

2. Data Tingkat Kecemasan Hospitalisasi Anak Usia 3-6 Tahun Sebelum Dan Sesudah Di Berikan Terapi Bermain Clay.

Berdasarkan tabel 5.5, didapatkan data bahwa tingkat kecemasan hospitalisasi seluruh responden 20 anak sebelum diberikan terapi bermain Clay (pre-test) dengan sesudah diberikan terapi bermain Clay (post-test) mengalami perubahan nilai Mean, Median, Variance, Nilai minimum, Nilai maximum, Range, Interquartile Range, Skewness, Kurtosis. 
Analisa Pengaruh Pemberian Terapi Bermain Clay Terhadap Kecemasan Hospitalisasi Anak Usia 3-6 Tahun Di Ruang Nusa Indah Rumah Sakit Tentara dr. Soepraoen Malang dengan menggunakan uji T Test.

\section{Merumuskan $H_{1}$}

$\mathrm{H}_{1}$ : Ada pengaruh pemberian terapi bermain Clay terhadap kecemasan dampak hospitalisasi anak Usia 3-6 tahun.

2. Penyajian Data

Data Hasil Sesudah Diberikan Terapi Bermain Clay Terhadap Kecemasan Hospitalisasi Anak Usia 3-6 Tahun Di Ruang Nusa Indah Rumah Sakit Tentara dr.Soepraoen Malang Berdasarkan tabel 4.8, didapatkan data bahwa dari 20 responden 100\% keseluruhan tingkat kecemasan menurun.

\section{PEMBAHASAN}

\section{Kecemasan Hospitalisasi Anak Usia 3-6 Tahun Di Ruang Nusa Indah Rumah Sakit Tentara dr. Soepraoen Malang Sebelum Diberikan Terapi Bermain Clay}

Dari hasil penelitian didapatkan bahwa sebelum diberikan perlakuan pemberian terapi bermain Clay didapatkan tingkat kecemasan hospitalisasi seluruh responden 20 anak sebelum diberikan terapi bermain Clay (pre-test) dengan tingkat kecemasan sebagian besar kecemasan ringan sebanyak 13 anak (65\%) dan hampir setengahnya sebanyak 7 anak mengalami kecemasan sedang $(35 \%)$.

Kecemasan sedang memungkinkan seseorang untuk memusatkan pada masalah yang selektif, namun dapat melakukan sesuatu terarah. Manifestasi yang terjadi pada tingkat ini yaitu kelelahan meningkat, kecepatan denyut jantung dan pernafasan meningkat, ketegangan otot meningkat, bicara cepat dengan volume tinggi, lahan persepsi menyempit, mampu untuk belajar namun tidak optimal, kemampuan konsentrasi menurun, mudah tersinggung, tidak sabar, mudah lupa, marah dan menangis. Sedangkan kecemasan ringan berhubungan dengan ketegangan dalam kehidupan keseharianya yang menyebabkan seseorang menjadi waspada dan meningkatkan lahan persepsinya. Manifestasi yang muncul pada tingkat ini adalah kelelahan, kesadaran tinggi, mampu belajar, motivasi meningkat dan tingkah laku sesuai situasi.

Faktor-faktor yang mempengaruhi kecemasan yaitu faktor kelemahan fisik dapat melemahkan kondisi mental individu sehingga memudahkan timbulnya kecemasan, trauma atau konflik dari pengalaman anak yang dapat munculnya gejala kecemasan sangat bergantung 
pada kondisi individu, dalam arti bahwa pengalaman-pengalaman emosional atau konflik mental yang terjadi pada individu akan memudahkan timbulnya gejala-gejala kecemasan dan faktor lingkungan awal yang tidak baik karena lingkungan adalah faktor utama yang dapat mempengaruhi kecemasan individu, jika faktor tersebut kurang baik maka akan menghalangi pembentukan kepribadian sehingga muncul gejala-gejala kecemasan (Rufaidah, 2009).

Berdasarkan penelitian dari keseluruhan 20 responden (100\%) kondisi fisik anak masih memungkinkan beraktifitas, dan kondisi anak tidak ada yang mengalami pengalaman buruk di rumah sakit, dan disekitar lingkungan dinding ruangan pasien terdapat tempelan gambargambar kartun yang membuat suasana ruangan tidak menyeramkan bagi anak, sehingga memicu angka kecemasan ringan yang paling banyak muncul. Penelitian di Amerika Serikat, diperkirakan lebih dari 5 juta anak menjalani hospitalisasi karena prosedur pembedahan dan lebih dari (50\%) dari jumlah tersebut, anak mengalami kecemasan dan stres. Diperkirakan juga lebih dari 1,6 juta anak dan anak usia antara 2-6 tahun menjalani hospitalisasi disebakan karena injury dan berbagai penyebab lainnya (Disease Control, National Hospital Discharge Survey (NHDS, 2004 dalam Apriliawati, 2011).

Menurut peneliti bahwa lingkungan rumah sakit itu sendiri merupakan penyebab kecemasan bagi anak, baik lingkungan fisik rumah sakit seperti bangunan atau ruang rawat, pakaian putih petugas kesehatan maupun lingkungan sosial seperti interaksi antara anak dengan perawat atau dengan petugas medis, anak menimbulkan sifat agresif dengan marah dan berontak, dan tidak mau bekerja sama dengan perawat atau tidak kooperatif dengan tindakan yang ada.

\section{Kecemasan Pada Anak Usia 3-6 Tahun Di Ruang Nusa Indah Rumah Sakit Tentara dr. Soepraoen Malang Sesudah Diberikan Terapi Bermain Clay}

Hasil penelitian didapatkan bahwa sesudah diberikan perlakuan pemberian terapi bermain Clay anak mengalami perubahan kecemasan. Keseluruhan responden (100\%) responden, didapatkan tingkat kecemasan hospitalisasi sesudah diberikan terapi bermain Clay (post-test) hari ke 2 dengan tingkat kecemasan sebagian besar tidak cemas sebanyak 12 (60\%), dan hampir setengahnya kecemasan ringan sebanyak 8 anak (40\%)

Bermain Clay akan melepaskan anak dari ketegangan dan kecemasan yang dialami. Karena dengan bermain anak akan dapat mangalihkan rasa sakitnya pada permainan (distraksi) dan relaksasi melalui kesenangannya dalam bermain. Akibat adanya distraksi dan relaksasi yang terjadi, anak yang mengalami cemas akhirnya menjadi tidak cemas lagi. Clay dapat meningkatkan daya pikir anak dan konsentrasi anak. Melalui Clay anak akan dapat mempelajari 
sesuatu yg rumit serta anak akan berpikir bagaimana Clay dapat terbentuk sesuai gambar atau cetakan dengan rapi. Pemberian terapi bermain Clay terhadap dampak hospitalisasi pada anak usia prasekolah yaitu ada pengaruh terhadap penurunan kecemasan, kehilangan kontrol, dan ketakutan pada anak yang dirawat di rumah sakit. Karena bermain merupakan aktivitas yang menyenangkan bagi anak-anak (Alfiyanti, 2010 \&Adriana, 2013).

Menurut hasil penelitian ini untuk mengurangi kecemasan akibat hospitalisasi sangat diperlukan, karena selain membuat anak menjadi lebih kooperatif juga menujang proses penyembuhan. Dengan melalui terapi bermain Clay dapat meminimalkan atau menurunkan kecemasan pada anak selama perawatan dan anak mempunyai koping yang positif sehingga akan membantu penyembuhan.

\section{Pengaruh Pemberian Terapi Bermain Clay Terhadap Kecemasan Hospitalisasi Anak} Usia 3-6 Tahun Di Ruang Nusa Indah Rumah Sakit Tentara dr. Soepraoen Malang

Hasil penelitian didapatkan bahwa sebelum dan sesudah diberikan perlakuan pemberian terapi bermain Clay anak mengalami perubahan kecemasan. Keseluruhan responden (100\%) responden. Dan Penelitian ini menggunakan uji T test dengan taraf kesalahan 5\% dan nilai Asymp.Sig (2-tailed)/ 0,000 lebih kecil dari < 0,05 sehingga $\mathrm{H}_{1}$ diterima dan $\mathrm{H}_{0}$ ditolak, artinya Ada Pengaruh Pemberian Terapi Bermain Clay Terhadap Kecemasan Hospitalisasi Anak Usia 3-6 Tahun Di Rung Nusa Indah Rumah Sakit Tentara dr. Soepraoen Malang.

Bermain Clay akan melepaskan anak dari ketegangan dan kecemasan yang dialami. Karena dengan bermain anak akan dapat mangalihkan rasa sakitnya pada permainan (distraksi) dan relaksasi melalui kesenangannya dalam bermain. Akibat adanya distraksi dan relaksasi yang terjadi, anak yang mengalami cemas akhirnya menjadi tidak cemas lagi. Clay dapat meningkatkan daya pikir anak dan konsentrasi anak. Melalui Clay anak akan dapat mempelajari sesuatu yg rumit serta anak akan berpikir bagaimana Clay dapat tersusun dengan rapi. Pemberian terapi bermain Clay terhadap dampak hospitalisasi pada anak usia prasekolah yaitu ada pengaruh terhadap penurunan kecemasan, kehilangan kontrol, dan ketakutan pada anak yang dirawat di rumah sakit. Karena bermain merupakan aktivitas yang menyenangkan bagi anak-anak (Alfiyanti, 2010 \& Adriana, 2013).

Pengalihan dari fokus perhatian terhadap kecemasan ke stimulus yang lain dengan cara distraksi dalam stimulasi penglihatan, pendengaran, dan sentuhan yang akan menghambat lebih cepat impuls kecemasan. Kecemasan pada anak prasekolah 3-5 tahun akan mengaktivasi hipotalamus dan selanjutnya melepaskan Hormone Corticotropic Realising Hormone (CRH). 
CRH menyebabkan hipofise anterior mengeluarkan Adenocorticotropic Hormone (ACTH). ACTH merangsang korteks adrenal melepaskan kortisol. Pemberian terapi bermain pada anak prasekolah yang dirawat dirumah sakit memberikan manfaat untuk kemampuan motorik halus anak, sekaligus merangsang kreativitas anak. Jika stressor kecemasan berupa perpisahan dapat diatasi maka tingkat kecemasan pada anak dapat menurun (Hockenbery, 2009).

Perasaan nyaman juga akan merangsang tubuh untuk mengeluarkan hormone endorphin. Peningkatan endorphin dapat menurunkan kecemasan pasien. Hormon endorphin merupakan hormone yang diproduksi oleh bagian hipotalamus di otak. Hormon ini menyebabkan otot menjadi rileks, sistem imun meningkat dan kadar oksigen dalam darah naik, sehingga dapat membuat pasien cenderung mengantuk dan dapat beristirahat dengan tenang. Hormon ini juga memperkuat sistem kekebalan tubuh untuk melawan infeksi dan dikenal sebagai morfin tubuh yang menimbulkan efek sensasi yang sehat dan nyaman. Selain mengeluarka hormone endorphin tubuh juga mengeluarkan GABA enkephalin. Zat-zat ini dapat menimbulkan efek analgesia sehingga nyeri pada anak prasekolah yang sakit dapat dikurangi atau dihilangkan.Jika stressor kecemasan yang dialami anak prasekolah dapat diatasi maka kecemasan yang dialami anak dapat menurun (Hockenbery, 2009).

Berdasarkan hasil penelitilain sebelumnya dari Anggerda tahun 2014 dirumah sakit umum PKU Muhammadiyah Bantul, Ada perbedaan antara sebelum dan sesudah perlakuan pada kelompok eksperimen. Terdapat perbedaan yang signifikan pada tingkat kecemasan anak usia pra sekolah yang dirawat inap di Rumah Sakit Umum Muhammadiah Bantul di kelompok eksperimen antara sebelum diberi terapeutik Clay dengan sesudah diberi terapeutik. Dapat disimpulkan bahwa terdapat perbedaan yang signifikan antara kelompok eksperimen yang diberi perlakuan permainan terapeutik Clay dengan kelompok kontrol yang tidak diberikan perlakuan sehingga dapat dinyatakan ada pengaruh pemberian terapi bermain Clay terhadap kecemasan hospitalisasi anak prasekolah Usia 3-6 tahun.

Menurut hasil dari penelitian ini membuktikan bahwa terapi bermain Clay memiliki pengaruh terhadap penurunan kecemasan anak Usia 3-6 tahun akibat hospitalisasi. Karena terapi bermain efektif mengurangi kecemasan yang di alami oleh anak akibat hospitalisasi.

\section{KESIMPULAN}

Berdasarkan hasil penelitian dan analisa data hasil pengukuran Kecemasan Hospitalisasi Anak Usia 3-6 Tahun sebelum dan sesudah Pemberian Terapi Bermain Clay Di Ruang Nusa Indah Rumah Sakit Tentara dr. Soepraoen Malang, didapatkan kesimpulan sebagai berikut: 
1. Kecemasan hospitalisasi sebelum diberikan Terapi Bermain Clay pada 20 responden didapatkan hasil sebagian besar anak mengalami kecemasan ringan (65\%), dan hampir setengahnya mengalami kecemasan sedang (35\%).

2. Kecemasan hospitalisasi sesudah diberikan Terapi Bermain Clay pada 20 responden didapatkan hasil sebagian besar anak tidak mengalami kecemasan (60\%) dan hampir setengahnya mengalami kecemasan ringan $(40 \%)$

3. Ada Pengaruh Pemberian Terapi Bermain Clay Terhadap Kecemasan Hospitalisasi Anak Usia 3-6 Tahun Di Ruang Nusa Indah Rumah Sakit Tentara dr.Soepraoen Malang dengan menggunakan uji T Test dengan hasil $\propto 0,000$ yang kurang dari $<0,05$.

\section{SARAN}

1. Hasil penelitian ini dapat dijadikan sebagai masukan bagi pengembangan pelayanan kesehatan dan dapat menyediakan terapi bermain Clay yang salah satu media untuk menghilangkan kecemasan hospitalisasi pada anak khususnya Usia 3-6 tahun sesuai tahapan usianya.

2. Bagi rumah sakit yang memiliki ruang perawatan anak, untuk menyediakan ruang khusus bermain dengan fasilitas permainan sesuai dengan tingkatan usia dan SOP agar anak bisa merasa senang (tidak cemas) dan bisa kooperatif dengan tindakan yang ada

Tabel 5.1 Distribusi Frekuensi Usia dan Jenis Kelamin Anak

\begin{tabular}{lll}
\hline & Frekuensi (anak) & Persentase (\%) \\
\hline Usia & & \\
3 tahun & 2 anak & $10 \%$ \\
4 tahun & 3 anak & $15 \%$ \\
5 tahun & 3 anak & $15 \%$ \\
6 tahun & 12 anak & $60 \%$ \\
Total & $\mathbf{2 0}$ anak & $\mathbf{1 0 0 \%}$ \\
\hline Jenis & \\
Kelamin & & \\
Laki-laki & 13 anak & $65 \%$ \\
Perempuan & 7 anak & $35 \%$ \\
Total & 20 anak & $\mathbf{1 0 0 \%}$ \\
\hline \multicolumn{2}{c}{ (Sumber: Lembar Observasi September 2017) }
\end{tabular}

Tabel 5.3 Karakteristik Kecemasan Sebelum dan Sesudah Pemberian Terapi Bermain Clay

\begin{tabular}{lll}
\hline Kecemasan & Frekuensi (anak) & Presentasi (\%) \\
\hline $\begin{array}{l}\text { Sebelum } \\
\text { Tidak }\end{array}$ & 0 anak & $0 \%$ \\
Cemas & & \\
Ringan & 13 anak & $65 \%$ \\
Sedang & 7 anak & $35 \%$ \\
Berat & 0 anak & $0 \%$ \\
\hline Sesudah & & \\
Tidak & 12 anak & $60 \%$ \\
Cemas & & \\
Ringan & 8 anak & $40 \%$ \\
Sedang & 0 anak & $0 \%$ \\
Berat & 0 anak & $0 \%$ \\
\hline
\end{tabular}

(Sumber: Lembar Observasi September 2017) 
Tabel 5.5 Hasil Uji T Test Dalam Bentuk Deskriptif Berdasarkan Tingkat Kecemasan Pre Test Dan Post Test

\begin{tabular}{|c|c|c|c|c|}
\hline \multicolumn{5}{|c|}{ Paired Samples Correlations } \\
\hline & & $\mathbf{N}$ & Correlation & Sig. \\
\hline Pair 1 & $\begin{array}{l}\text { PRE_PERLAKUAN \& } \\
\text { POST_PERLAKUAN }\end{array}$ & 20 & .824 & .000 \\
\hline
\end{tabular}

(Sumber: Lembar Observasi September 2017)

Tabel 5.8 Tabel Data Kecemasan Hospitalisasi Anak Usia 3-6 Tahun Sesudah Diberikan Terapi Bermain Clay

\begin{tabular}{lcl}
\hline Kategori Perubahan Kecemasan & Frekuensi (anak) & Presentasi (\%) \\
\hline Menurun & 20 anak & $100 \%$ \\
\hline Tetap & 0 anak & $0 \%$ \\
\hline Meningkat & 0 anak & $0 \%$ \\
\hline
\end{tabular}

(Sumber: Lembar Observasi September 2017)

\section{DAFTAR PUSTAKA}

Adriana, Dian. (2013). Tumbuh Kembang dan Terapi Bermain pada Anak.Jakarta: Salemba Medika. Diakses pada tanggal 11-11-2016 pukul 19.10 WIB.

Alfiyanti, N. (2010). Upaya Meningkatkan Daya Pikir Anak Melalui Permainan Edukatif. http://etd.eprints.ums.ac.id/9837/1/A520085042.pdf. Diakses pada tanggal 11-11-2016 pukul 19.15 WIB.

Apriliawati, Anita. (2011). Pengaruh Bibloterapi Terhadap Tingkat Kecemasan Anak Usia Sekolah yang Menjalani Hospitalisasi di Rumah Sakit Islam Jakarta. Fakultas Ilmu Keperawatan Universitas Indonesia. Diakses pada tanggal 11-11-2016 pukul 19.20 WIB.

Hildayani Rini dkk. 2006. Psikologi Perkembangan Anak. Jakarta: Unversitas Jakarta: Depdiknas

Hildayani, Rini. dkk. 2011. Psikologi Perkembangan Anak. Universitas Terbuka. Jakarta

Hockenberry, J.M. \& Wilson, D. 2007. Wong 's nursing care of infant and children. 8 th edition. Canada: Mosby Company.

Rufaidah, Elina Rharisti. (2009). Efektifitas Terapi Kognitif terhadap Penurunan Tingkat Kecemasan pada Penderita Asma di Surakarta. Tesis. Fakultas Psikologi-UGM. Diakses pada tanggal 11-11-2016 pukul 19.25 WIB.

Supartini, Y. 2012. Buku Ajar Konsep Dasar Keperawatan Anak. Jakarta: EGC

Supartini, Y. 2012. Konsep Dasar Keperawaatan Anak. Jakarta: EGC. 